\title{
Understanding transnational political involvement among Senegalese migrants: The role of acculturation preferences and perceived discrimination
}

\author{
Eva G.T. Green ${ }^{\mathrm{a}, *}$, Oriane Sarrasin ${ }^{\mathrm{a}}$, Jenny Maggi ${ }^{\mathrm{b}}$ \\ a Faculty of Social and Political Sciences, University of Lausanne, Geopolis, CH-1015 Lausanne, Switzerland \\ b Sociology Department, University of Geneva, Bd. du Pont d'Arve 40, CH-1211 Genève, Switzerland
}

\section{A R T I C L E I N F O}

\section{Article history:}

Received 12 March 2013

Received in revised form 7 February 2014

Accepted 5 May 2014

\section{Keywords:}

Transnational political involvement

Acculturation strategies

Perceived discrimination

Collective action

Senegal

\begin{abstract}
A B S T R A C T
In political debates, migrants' political involvement in their countries of origin and successful adaptation to receiving countries are often portrayed as incompatible. We address this concern by examining the links between acculturation preferences, perceived discrimination, and migrants' transnational political involvement in their country of origin. In line with collective action research, a cross-sectional questionnaire study $(N=84)$ among Senegalese migrants in Paris (France) and Geneva (Switzerland) examined three pathways to transnational political involvement (motivations and actual behaviour). Perceived discrimination, the grievances pathway, was positively related to both transnational motivations (but only when desire to adopt the receiving culture was low) and political behaviour in Senegal. Desire to adopt the culture of the receiving society as an acculturation preference, the embeddedness pathway, was also positively linked to transnational motivations and political behaviour. Finally, desire to maintain the culture of origin as an acculturation preference-the collective identification pathway-was unrelated to transnational political involvement. These findings underscore the compatibility of transnational political involvement in countries of origin and adaptation to receiving societies. We discuss the pivotal role of political psychology in bringing together acculturation psychology and transnationalism studies.
\end{abstract}

(c) 2014 Elsevier Ltd. All rights reserved.

\section{Introduction}

The political involvement of migrants is a sensitive topic in contemporary democracies. On the one hand, the conditions for enabling political participation in receiving countries through voting rights or naturalisation are debated. On the other hand, migrants' political involvement in their countries of origin raises doubts about loyalty to the receiving country. Concerns about the compatibility of such involvement with migrants' adaptation have been expressed. To address such concerns, during its first session held in Brussels, the Global Forum on Migration and Development (2007) invited the research community to study the links between the adaptation of migrant communities in receiving countries and their transnational activities related to development in home countries. The current paper aims to shed light to this question by examining how the ties migrants seek with and the way they are treated by the receiving country, as well as their relationship with the

\footnotetext{
* Corresponding author. Tel.: +41 216923884.

E-mail addresses: eva.green@unil.ch (E.G.T. Green), os32@sussex.ac.uk (O. Sarrasin), jenny.maggi@unige.ch (J. Maggi).
} 
country of origin, link to transnational political involvement. Social psychological acculturation and collective action literature can contribute to the debate on the compatibility of migrants' adaptation and transnational activities by investigating the relationship between acculturation preferences, perceived discrimination, and transnational political involvement.

Research on transnational behaviour has shown how socio-structural factors (e.g., length of residence, employment) and social skills acquisition (e.g., language skills) relate to affiliations and patterns of exchange, including political involvement in countries of origin. While social psychological research has for over two decades examined the psychological and intergroup outcomes of migrant acculturation within receiving countries (for overviews, Brown \& Zagefka, 2011; Sam \& Berry, 2006), links between acculturation preferences and political behaviour in countries of origin have received little attention (see van Oudenhoven \& Ward, 2013; van Oudenhoven, Ward, \& Masgoret, 2006). To fill this gap, we use notions from collective action research to bridge transnationalism and acculturation research. We first define transnational motivations and political behaviour. Second, we summarise the debate on the compatibility between adaptation in receiving countries and transnational political involvement in countries of origin. Third, drawing on research on antecedents of collective action, we argue that transnational political involvement is determined by perceived discrimination and acculturation preferences, defined as grievances, embeddedness, and collective identification. We examine our assumptions in a cross-sectional study conducted among Senegalese migrants in Switzerland and France recruited through Senegalese associations.

\subsection{Transnational motivations and political behaviour in countries of origin}

The growing interdisciplinary field of transnationalism studies has defined transnationalism as increased family, social, cultural, religious, economic, and political interlinkages between people across the borders of nation-states (e.g., Basch, Glick Schiller, \& Blanc-Szanton, 1994, Kivisto, 2001; Levitt \& Jaworsky, 2007; Portes, 2001; Vertovec, 2009). Such links have existed, to various degrees, throughout history but are now facilitated by improved transportation, technology, and telecommunication.

Transnational political involvement can be divided into motivations to transnational activities (labelled commitment or capabilities) and actual transnational activities (Al-Ali, Black, \& Koser, 2001; Bloch, 2008). Transnational motivations refer to the abilities and willingness to engage in, and dedication to political, economic, and social activities in countries of origin (Al-Ali et al., 2001). For example, the desire to contribute to the development of countries of origin depicts transnational motivations (e.g., Bloch, 2008). These motivations promote collaboration and solidarity within migrant communities in receiving countries as well as mobilisation for a common purpose, for example through participation in migrant associations (Faist, 2008). Indeed, migrant associations are seen as central actors in the development of countries of origin. In the current research, we examine solidarity- and development-related motivations to participate in migrant associations in receiving countries.

Transnational political behaviour, in turn, consists of migrants' actual electoral and non-electoral political activities in their countries of origin. Electoral activities include for example membership in a political party in the country of origin, participation in political campaigning and monetary contributions to these parties, whereas non-electoral activities include membership in non-governmental local associations (NGOs) and monetary contributions to these associations (Guarnizo, Portes, \& Haller, 2003). Non-electoral activities are also considered to have political force to the extent that they influence governments of countries of origin for example by determining which projects in local communities receive financial support. These facets of transnational political behaviour are examined in the current research.

\subsection{The relationship between transnational behaviour and adaptation}

The relationships between transnational cross-border political involvement and migrants' adaptation to the receiving country have been debated in academic migration research. According to assimilation theory, immigrants are expected to adapt to the cultural and economic systems of the receiving country and over time shed the cultural practices of their countries of origin (e.g., Alba \& Nee, 1997; see Erdal \& Oeppen, 2013; Kivisto, 2001 for a discussion). From this perspective, adaptation and transnational activities are antagonistic. Maintaining strong, in particular political ties with one's country of origin supposedly puts migrants in a position of dual loyalty that will impede adaptation in the receiving country and ultimately marginalise migrants. Transnationalism scholars have contested this vision and argued that transnational political involvement and adaptation are not mutually exclusive, but compatible (see Erdal \& Oeppen, 2013; Guarnizo et al., 2003; Portes, 2003; Smith \& Bakker, 2008; Tamaki, 2011) Indeed, pursuing transnational activities in home countries requires financial and relational resources. Acquisition of these resources is facilitated through adapting to the receiving culture by joining the job market and by seeking connections with members of the receiving culture, in addition to compatriots (e.g., Al-Ali et al., 2001; Snel, Engbersen, \& Leekers, 2006).

In the transnationalism literature, adaptation to the receiving country has typically been assessed with language knowledge, length of residence in or citizenship of the receiving country (this differs from the notion of sociocultural adaptation that refers to cognitive and behavioural dimensions of adaptation, see Ward \& Kennedy, 1999). These factors have been demonstrated to positively relate to transnational political behaviour (e.g., Bermudez, 2010; Guarnizo et al., 2003; Lacroix, 2009; Portes, 2003; Tamaki, 2011). Other socio-structural factors such as gender, employment or education also affect participation in transnational activities (see Carling \& Hoelscher, 2013). For example, among Dominican and Salvadoran migrants in the U.S., men, higher educated, and those with large social networks were more likely to engage in transnational political 
activities (Guarnizo et al., 2003). In a survey study among migrants from the U.S., Japan, Iraq, former-Yugoslavia, Morocco, and the Dutch Antilles in the Netherlands, Snel and colleagues (2006) showed nevertheless that the link between adaptation and transnational activities in home countries was not straightforward. Having Dutch natives in one's social network was unrelated to transnational activities. Identification with Dutch natives, in turn, was positively related to transnational economic activities, negatively related to cultural activities, and unrelated to political activities.

Whereas the work of transnationalism scholars has revealed relationships between transnational activities and indicators of socio-structural adaptation and skills acquisition, the relationship between social psychological factors and transnational political involvement in home countries is yet to be examined (for an exception, the measurement of degree of identification in Snel et al., 2006).

\subsection{Acculturation preferences, perceived discrimination, and transnational political involvement}

On arrival to a new home country, migrants need to negotiate the relationship they want to entertain with the receiving country as well as with their country of origin. The psychological and behavioural changes occurring when migrants arrive in the receiving country are referred to as acculturation processes (e.g., Sam \& Berry, 2006). In the influential model of John Berry, attitudes towards these processes are described by means of two orthogonal dimensions (Berry, 1990, 2006a): The desire to develop contacts with the receiving society on the one hand and the desire to maintain the culture of one's country of origin on the other (see also Bourhis, Moïse, Perreault, \& Senécal, 1997; Brown \& Zagefka, 2011; Ward \& Kus, 2012). The crossing of these dimensions produces four acculturation preferences. Integration refers to a migrant's simultaneous desire to maintain the culture of origin and to develop contacts with the receiving society. Marginalisation denotes the opposite by rejecting both the culture of the country of origin and of the receiving society. Assimilation involves adopting the culture of the receiving society and abandoning one's culture of origin, whereas separation involves maintaining one's culture of origin and rejecting the culture of the receiving society. Integration has been shown to result in the best acculturation outcomes in terms of psychological well-being (e.g., life satisfaction, self esteem) and socio-economic adaptation, whereas marginalisation has resulted in the worst outcomes (Berry, 2006b).

In addition to making acculturation choices, migrants may experience discrimination when encountering the receiving country. Indeed, acculturation preferences do not develop in a vacuum as migrants interact with the majority population and institutions of the receiving society (van Oudenhoven et al., 2006; see Phalet \& Kosic, 2006 for an overview on the European context). Thus, acculturation choices are affected by prevailing integration policies, history of immigration, and number of migrants in the receiving country and so forth (e.g., Berry, 2006a; Bourhis et al., 1997; Navas et al., 2005). The interactions with the receiving society can be experienced as more or less discriminatory. Perceiving oneself a target of discrimination is an important acculturative stressor (e.g., Jasinskaja-Lahti, Liebkind, Horenczyk, \& Schmitz, 2003) which can affect acculturation orientations (e.g., Te Lindert, Korzilius, van der Vijver, Kroon, \& Arends-Tóth, 2008; Verkuyten \& Thijs, 2002). Therefore, the way intergroup relations play out in receiving societies has psychological and social consequences for migrants (see also Schmitt \& Branscombe, 2002).

To further understand how both migrants' acculturation preferences and the extent to which they experience discrimination shape their transnational political involvement (i.e., motivations to participate in migrant associations and political behaviour), we use notions from collective action research (see Klandermans, van der Toorn, \& van Stekelenburg, 2008; van Stekelenburg, 2013; see also Simon \& Grabow, 2010; van Zomeren, Postmes, \& Spears, 2008). Klandermans et al. (2008) demonstrated that grievances, embeddedness, and collective identification underlie collective action among migrants in receiving countries (e.g., participation in rallies and demonstrations). We apply this reasoning to political involvement in countries of origin because, like collective action in receiving countries, it aims at improving the situation of the ingroup. These three pathways enable us to organise arguments from the transnationalism literature in a single model and relate perceived discrimination and acculturation preferences to transnational political involvement in countries of origin.

First, grievances-feeling disrespectfully treated-drive political participation and claim making among migrants (Klandermans et al., 2008). Feelings of dissatisfaction and indignation as a result of such treatment motivate political activities. Perceived discrimination due to ethnic or national origin experienced in the receiving country exemplifies grievances encountered by migrants. Discrimination and lack of recognition encourage turning towards home communities. Transnational activities in countries of origin can offer "a source of solace" (Portes, 2003, p. 880) and compensate for immigrants' status loss (Guarnizo et al., 2003). We thus expect that perceptions of discrimination in the receiving country relate positively to transnational political involvement.

Second, migrants' embeddedness in social networks in the receiving country nurtures political trust and increases symbolic and material resources which then drive political involvement in home countries (e.g., Fennema \& Tillie, 1999; Guarnizo et al., 2003). Moreover, the feeling of belongingness in the receiving country gives confidence to further develop connections, here transnational political involvement, in the home country (Erdal \& Oeppen, 2013; Vertovec, 2009). The co-existence of adaptation and transnational involvement is synergistic when the increase in one gives confidence to increase the other. As wanting to adopt the culture of the receiving country as an acculturation preference denotes a desire for embeddedness, cultural adoption is expected to relate to transnational political involvement.

Grievances and embeddedness, however, are contradictory experiences that may coexist. For example, Beque (2005) showed that second-generation migrants in France-very likely more adapted in the receiving society than first-generation migrants-were more sensitive to experiences of discrimination, in particular when they had a high level of education. 
Moreover, Berry and Sabatier (2010) revealed that migrants in Paris preferring integration perceived more discrimination than those preferring assimilation, suggesting that adopting the culture of the receiving society is an insufficient shield against discrimination. Desiring to adopt the receiving culture but simultaneously experiencing discrimination from the very group one wants to adapt to is discouraging and frustrating (e.g., Jasinskaja-Lahti, Liebkind, \& Solheim, 2009; Schmitt \& Branscombe, 2002). It is unclear how this affects transnational political activities. We thus also explore the interactive effect of cultural adoption and perceived discrimination in the current study.

Third, collective identification (i.e., giving importance to being a member of the country of origin) fosters political and social movement participation (e.g., Stürmer \& Simon, 2004). For example, migrants' ethnic identification was found to relate to collective action tendencies (Deaux, Reid, Martin, \& Bikmen, 2006) and to active support for minority rights (Verkuyten \& Yildiz, 2006; see however, Klandermans et al., 2008). While cultural maintenance and identification are not interchangeable notions, both entail having strong ties with one's country of origin and fellow citizens (see Brown \& Zagefka, 2011, for an overview). We thus expect that the desire to preserve links with one's country of origin as an acculturation preference relates to transnational political involvement in the country of origin.

As adopting the culture of the receiving country and maintaining links with the country of origin should both relate to transnational political involvement, their simultaneous presence, the integration preference in the acculturation typology, should be particularly propitious for transnational involvement. Indeed, "integrated migrants, who value both cultural maintenance and contact with the host society, may extend or strengthen their means of cultural maintenance through association with their country of origin" (van Oudenhoven \& Ward, 2013, p. 90). Verkuyten and Martinovic (2012) also highlight the importance of dual identification for conventional politicisation of migrants, i.e., signing petitions, participation in demonstrations, as opposed to radical politicisation. However, a negative link between desire for cultural adoption and transnational political involvement coupled with a positive link between cultural maintenance and transnational involvement would support the concern voiced by the assimiliationist approach that fostering cross-border relations disrupts integration and loyalty to the receiving country. Therefore, the interactive effect of desires to adopt the receiving culture and to maintain the culture of origin is explored.

\section{Studying transnational behaviour among Senegalese migrants in Paris and in Geneva}

The links between acculturation preferences, perceived discrimination, and transnational political involvement were examined in a cross-sectional study among Senegalese migrants that are members of Senegalese associations in Paris (France) and Geneva (Switzerland). The questionnaire was part of a larger research project on the role of transnational Senegalese organisations in both integration in the receiving country and development of the country of origin. ${ }^{1}$

The emigration rate from Senegal is estimated between half million and two million international migrants out of a population of twelve million (Fall, Hernández Carretero, \& Sarr, 2010; Some, 2009). Senegalese migration is characterised by economic, socio-cultural, and political transnationalism resulting in well-organised and active migrant organisations in receiving countries, especially in France (Lacroix, Sall, \& Salzbrunn, 2008). The transnational activities of these associations contribute to the development of Senegal notably through stimulating trade and building sectors, being involved with local politics, as well as improving living conditions of families and communities. Given the colonial past of France in Senegal (French is still a national language), France has been one of the main migration destinations in Europe. Senegalese migrants have included, for example, colonial soldiers that remained in France after the world wars, labour migrants initially from the Senegal River Valley, students, migrants resulting from family reunification and commercial networks of the Murid brotherhood, a Muslim order established in Senegal at the end of the nineteenth century (e.g., Riccio, 2005). Currently, the Senegalese diaspora in Paris originate from all regions of Senegal and from all social classes including second and even third generation migrants. In Switzerland, the Senegalese community is smaller, due to the restrictive Swiss immigration legislation, and has arrived more recently. The community is composed to a greater extent of students and high-skilled migrants, many working in international organisations, but also of Senegalese migrating through family reunification. In addition to differences in composition and size of the Senegalese community, the two cities differ in integration and immigration policies as well as in practices of including migrant associations in the development of countries of origin (Maggi, Sarr, Green, Sarrasin, \& Ferro, 2013). In Paris, there is a tradition of co-development, where return migration is supported in parallel to co-financing development projects of migrant associations. In Geneva, in turn, there is no specific policy for co-financing migrant associations in their development activities, but a global policy of support for developing countries to set up policies to take advantage of their diaspora in development activities.

Paris and Geneva are nevertheless similar on other dimensions: Both are French-speaking cities with laic traditions (Canton of Geneva compared to the more religious cantons in Switzerland) and have a highly multicultural demographic composition that can be portrayed as "super-diverse" (Vertovec, 2007). Importantly, both have active Senegalese diaspora

\footnotetext{
${ }^{1}$ Fieldwork was also conducted in Milan (Italy). Whereas in the two French-speaking cities (i.e., Paris and Geneva) questionnaires were self-administrated and in French, an official language in Senegal, two data collection methods were used in Milan (self-administration vs. interviewer-administration), and partially using questionnaires in Italian, a language in which respondents reported to be less fluent. To prevent introducing unnecessary bias due to data collection (e.g., Heath, Martin, \& Spreckelsen, 2009) and language (e.g., Davidov \& De Beuckelaer, 2010), data from Milan were not included in the present study.
} 
associations. Though mean levels of transnational political involvement may differ, we do not expect the differences between the two cities (e.g., in migration rates) to affect the direction of the relationships between acculturation preferences, perceived discrimination and transnational political involvement.

By articulating transnationalism literature and the three pathways revealed in collective action research, we predict that perceived discrimination as well as both the desire to adopt the French or the Swiss culture and the desire to maintain the Senegalese culture are positively related to transnational political involvement. Moreover, we explore the extent to which the desires for cultural adoption and for maintenance of one's culture of origin interact as well as whether the cultural adoption interacts with perceived discrimination in predicting transnational political involvement. The examined transnational political involvement covers on the one hand motivations to participate in migrant associations having an impact in Senegal and on the other hand political behaviour in Senegal.

\section{Method}

\subsection{Participants and procedure}

Eighty-four Senegalese (37 living in Paris and 47 living in Geneva) participated in the study. Participants were recruited through Senegalese associations focusing on political, development, and spiritual activities. Project researchers approached association representatives and distributed questionnaires at association meetings. Association members participated on a voluntary basis and were informed that the survey was anonymous. Participants were predominantly male (75\%) reflecting the lower migration rates of Senegalese women (16\% according to Some, 2009), their ages ranged from 19 to 60 years $\left(M_{\text {Paris }}=32\right.$ years, $M_{\text {Geneva }}=33$ years $)$. With the exception of two participants born in France, they all reported Senegal as their country of birth, and had lived in the country between 1 year and 24 years ( $M_{\text {Paris }}=9$ years, $S D=5.51, M_{\text {Geneva }}=5$ years, $S D=4.50, t(1,77)=3.41, p<.001)$. For both age and years of residence in the country outliers $\left(M+3^{*} S D\right.$; one case for age, and two for years of residence) were replaced by the cut-off value. In Paris, the majority had a permanent status $(N=19)$, while 13 reported having a temporary permit, one person had another status, and four did not provide information on their status. In Geneva, the majority $(N=33)$ reported having a temporary permit, while six had a permanent legal status (one had Swiss citizenship), six reported having another status, and two did not provide information on their status. Fifty-eight percent had studied or were studying to obtain a university degree ( $46 \%$ in Paris, $68 \%$ in Geneva, $\chi^{2}(1)=4.17, p=.041$ ). Respondents perceived on average their personal financial situation to be modest (on a scale from $1=$ very modest to $5=v e r y$ comfortable, $\left.M=2.38, S D=0.87 ; M_{\text {Paris }}=2.76, S D=0.87, M_{\text {Geneva }}=2.11, S D=0.78, t(76)=3.76, p<.001\right)$. Note that no respondent chose the fifth response category. Finally, mirroring the religious composition in Senegal, 96\% reported to have Muslim faith (96.6\% in Paris, 95.7\% in Geneva).

\subsection{Measures}

\subsubsection{Transnational motivations}

Motivations to participate in Senegalese migrant associations that have an impact on Senegal was measured with a threeitem score $\left(\alpha_{\text {Paris }}=.89, \alpha_{\text {Geneva }}=.75\right)$. Participants were asked on a 5 -point scale (from $1=$ not at all to $5=y e s$, totally) whether their participation in associations in the receiving countries was motivated by improving development cooperation policies, improving socio-economic development in Senegal, and solidarity with Senegalese in Senegal.

\subsubsection{Transnational political behaviour}

Active participation and sending monetary remittances were assessed with a four-item score $\left(\alpha_{\text {Paris }}=.64, \alpha_{\text {Geneva }}=.79\right.$ ). The respondents were asked on a 5 -point scale (from $1=$ not at all to $5=$ very much) whether they were active in a political party in Senegal and in a NGO/association in Senegal. The respondents also indicated whether they transferred funds to political parties and to NGOs (from $1=$ hardly ever to $5=$ very often).

\subsubsection{Predictors of transnational political involvement}

Acculturation attitudes were measured on a 5 -point scale from $1=$ not at all to $5=y e s$, totally. To maintain the brevity of the questionnaire, we opted for short measures (e.g., Berry \& Sabatier, 2011) adapted to the Senegalese migration context. An Importance of cultural adoption score was created with two items (importance to adapt to the culture and values of Paris/Geneva; importance to take interest in social and cultural life of Paris/Geneva; $\alpha_{\text {Paris }}=.89, \alpha_{\mathrm{Geneva}}=.88$ ). An Importance of cultural maintenance score was also created with two items (importance to maintain your Senegalese culture and values; importance to maintain your religious practice; $\alpha_{\text {Paris }}=.91, \alpha_{\text {Geneva }}=.68$ ).

Perceived discrimination was tapped with six items. Respondents were asked the extent (from $1=$ not at all to $5=$ very $m u c h$ ) to which Senegalese in Geneva/Paris were discriminated when looking for work, in the street and in shops, and by officials (e.g., police, hospital) as well as the extent to which the respondents had experienced discrimination in these situations. As perceived group and personal discrimination items loaded on the same factor in preliminary factor analyses and were strongly correlated, one perceived discrimination score was created $\left(\alpha_{\text {Paris }}=.85, \alpha_{\text {Geneva }}=.93\right)$. No evidence of personal $/$ group 
Table 1

Means of transnational political involvement, acculturation attitudes, and perceived discrimination in Paris and Geneva.

\begin{tabular}{|c|c|c|c|c|c|}
\hline & \multicolumn{2}{|l|}{ Paris } & \multicolumn{2}{|c|}{ Geneva } & \multirow[t]{2}{*}{$p$} \\
\hline & $M$ & $S D$ & $M$ & $S D$ & \\
\hline Transnational motivations & 3.61 & 1.06 & 3.91 & 0.95 & .18 \\
\hline Transnational behaviour & 2.34 & 1.00 & 1.57 & 0.81 & .001 \\
\hline Cultural adoption & 3.86 & 1.14 & 3.65 & 1.06 & .40 \\
\hline Cultural maintenance & 4.63 & 0.79 & 4.84 & 0.39 & .11 \\
\hline Perceived discrimination & 2.95 & 0.94 & 2.94 & 1.20 & .97 \\
\hline
\end{tabular}

Note: All scales from 1 (not at all/hardly ever) to 5 (yes totally/very often/very much).

discrimination discrepancy was revealed (Taylor, Wright, Moghaddam, \& Lalonde, 1990), that is, the degree of group and personal discrimination did not differ.

\section{Results}

\subsection{Descriptive results}

Descriptive findings in the two cities are displayed in Table 1. Senegalese in Paris and in Geneva had similar levels of transnational motivations. The Parisian Senegalese reported more frequent, albeit moderate, levels of transnational political behaviour than the Genevan Senegalese. The Senegalese in Paris and Geneva both found it important to adopt the receiving culture, but also to maintain their culture of origin. The importance of cultural maintenance was greater than that of cultural adoption in Paris, $t(34)=3.98, p<.001$, and in Geneva, $t(46)=6.75, p<.001$. Both reported only occasional discrimination.

\subsection{Predicting transnational political motivations and behaviour}

We next examine the predicted pathways to transnational political activities. Regression analyses were conducted on transnational motivations and behaviour with Stata 10 using robust standard errors. ${ }^{2}$ All continuous measures were standardised. The effects of the receiving city, years spent in the receiving country, gender, age of respondent, education (dummy variable, University vs. other) and subjective financial situation were entered in the model in a first step (Model 1). In Model 2 , the cultural adoption, cultural maintenance, and perceived discrimination scores were entered in the model to assess their relationship with transnational motivations and political behaviour. We were also interested in the interplay between cultural adoption and cultural maintenance in transnational political involvement and how the incongruent experiences of wanting to adopt the receiving culture but perceiving discrimination affect such activities. Therefore, in Model 3, the Adoption $\times$ Maintenance and Adoption $\times$ Perceived discrimination interaction terms were also included. In preliminary analyses, Maintenance $\times$ Perceived discrimination and Adoption $\times$ Maintenance $\times$ Perceived discrimination interaction terms were entered in the model. Moreover, due to slight differences between Paris and Geneva in sample composition and transnational behaviour, in additional analyses the receiving city was included in interaction terms with the main predictors. Since no predictions were made for these interactions, and since none of them yielded significant effects, they were omitted from further analyses. Insofar as the sample size is small for the number of predictors, in additional models the impact of the main predictors was assessed without the sociodemographic controls. The findings were not altered. The upper panel of Table 2 reports the final interpreted models for transnational political motivations and behaviour, whereas the lower panel displays changes in explained variance in model building.

\subsubsection{Transnational motivations}

Model 3 in Table 2 reveals that desire to adopt the receiving culture and perceived discrimination were positively related to transnational motivations showing evidence that both embeddedness and grievances underlie the motivation to participate in the activities of Senegalese associations in receiving countries. Moreover, while the increase in explained variance between Models 2 and 3 was marginal when both interactions were included (see lower panel of Table 2), the inclusion of the Adoption $\times$ Perceived discrimination interaction term alone significantly increased explained variance $\left(\Delta R^{2}=.08\right.$, $p=.01$ ). In Fig. 1, simple slopes (calculated at $1 S D$ above and below mean adoption; Aiken \& West, 1991) revealed that, when desire to adopt the receiving culture was high, transnational motivations were high and unrelated to perceived discrimination $(b=0.01, S E=0.13, p=.94)$. Only when desire to adopt was low, perceived discrimination played a role: The more the

\footnotetext{
2 Robust standard errors ensure inference consistency (for a discussion, see Antonakis, Bendahan, Jacquart, \& Lalive, 2010). The distribution of residuals in the current regression analyses failed to meet the homoscedasticity requirement. Moreover, the sample size was small. This might bias coefficient estimates, in particular estimates of standard errors, leading to inconsistent and uninterpretable $t$ statistics for the parameters (White, 1980). The regression coefficients are identical to the estimates of OLS regression analysis, but the standard errors are robust against failure to meet OLS assumptions. In our study, OLS regression analyses revealed essentially identical results.
} 
Table 2

Final models of hierarchical regressions for transnational political involvement (standardised regression weights).

\begin{tabular}{|c|c|c|}
\hline Predictor & $\begin{array}{l}\text { Transnational motivations } \\
\text { Model } 3 \\
\beta\end{array}$ & $\begin{array}{l}\text { Transnational behaviour } \\
\text { Model } 2 \\
\beta\end{array}$ \\
\hline \multicolumn{3}{|l|}{ Control variables } \\
\hline Geneva & .17 & $-.24^{\dagger}$ \\
\hline Age & -.01 & -.01 \\
\hline Women & .13 & .14 \\
\hline Length of residency & -.16 & .09 \\
\hline University & -.05 & -.13 \\
\hline Perceived financial situation & .19 & -.12 \\
\hline \multicolumn{3}{|l|}{ Main predictors } \\
\hline Adoption & $.29^{*}$ & $.26^{* *}$ \\
\hline Maintenance & .03 & .05 \\
\hline Perceived discrimination & $.24^{*}$ & $.32^{*}$ \\
\hline Adoption $\times$ Maintenance & -.08 & \\
\hline Adoption $\times$ Perceived discrimination & $-.26^{* *}$ & \\
\hline \multicolumn{3}{|l|}{ Explained variance in model building } \\
\hline$R_{\text {Model2 }}^{2}$ & .14 & $.29^{* * *}$ \\
\hline$\Delta R_{\text {Model2-Model1 }}^{2}$ & $.10^{\dagger}$ & $.14^{* *}$ \\
\hline$R_{\text {Model 3 }}^{2}$ & $.21^{*}$ & $.31^{* * *}$ \\
\hline$\Delta R_{\text {Model 3-Model2 }}^{2}$ & $.07^{\dagger}$ & .02 \\
\hline
\end{tabular}

Note:

$\dagger p<.10$.

$p \leq .05$.

${ }^{* *} p \leq .01$.

${ }^{* * *} p \leq .001$

respondents perceived discrimination the more motivated they were to participate in activities of Senegalese associations $(b=0.50, S E=0.17, p=.005)$. The model explained $21 \%$ of variance, $F(11,62)=2.14, p=.03$.

\subsubsection{Transnational behaviour}

Model 2 in Table 2 reveals that transnational political behaviour in Senegal was significantly and positively related both to perceived discrimination in the receiving society (i.e., grievances) and the desire to adopt the culture (i.e., embeddedness). Moreover, after accounting for acculturation attitudes, perceived discrimination, and socio-demographic controls, the Senegalese in Paris still reported more, albeit marginally, transnational political behaviour than the Senegalese in Geneva. The model explained $29 \%$ of variance, $F(9,64)=3.56, p=.001$. The lower panel of Table 2 shows that explained variance did not increase significantly when both interactions were included in Model 3.

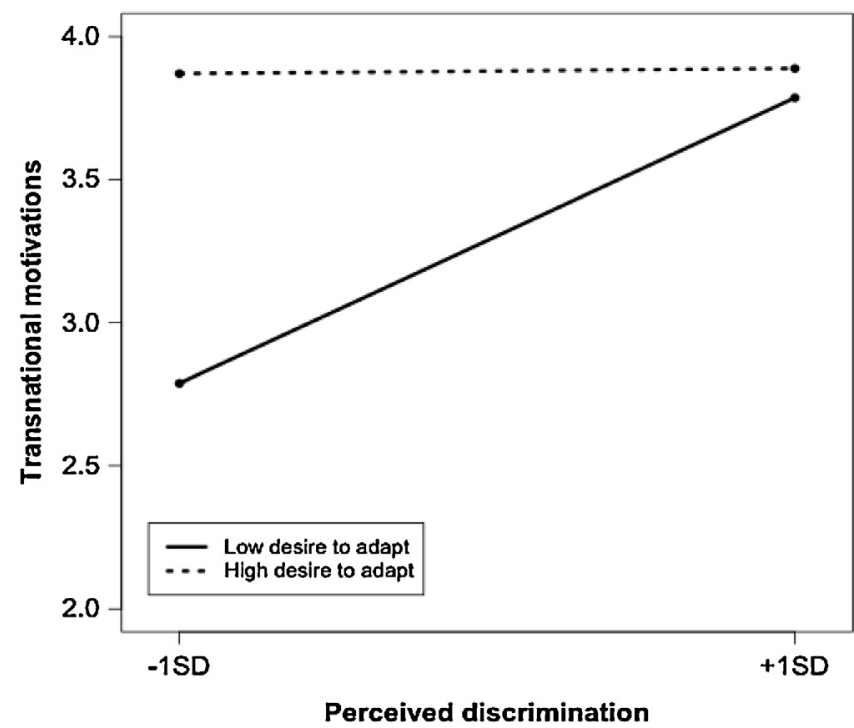

Fig. 1. Transnational motivations as a function of desire for cultural adoption and perceived discrimination. 


\section{Discussion}

Bringing together transnationalism, acculturation, and collective action literature, this paper examined the social psychological underpinnings of transnational political involvement, which has thus far mainly been explained with socio-structural factors. The findings of this research demonstrate that perceived discrimination and desire to adopt the receiving culture-the predicted grievances and embeddedness pathways-relate to transnational motivations and political behaviour of Senegalese migrants over and above respondents' socio-demographic factors (e.g., socio-economic situation) and city of residence. Perceived discrimination was related to transnational political behaviour, as well as to transnational motivations but, in this last case, only when desire to adopt the receiving culture was low. Importantly, in support of the transnationalism perspective, desire for cultural adoption was positively related to transnational motivations and political behaviour, whereas cultural maintenance was unrelated.

\subsection{Further examination of pathways to transnational political involvement}

In line with the collective action literature, we found that grievances (i.e., perceived discrimination) were related to transnational political involvement. Recent research demonstrating the moderating role of societal position in explaining different pathways to collective action suggests that this relationship could be particularly prominent among Senegalese migrants. Indeed, in a study conducted in the Netherlands, van Stekelenburg (2013) showed that collective action among Muslims (a frequently stigmatised, lower status group in the country) was more likely driven by grievances and political cynicism, whereas the collective action of Jews (a higher status group) was more likely resulting from embeddedness and feelings of efficacy. The participants of our study are black Africans of predominantly Muslim faith, more frequently stigmatised than other groups of migrants (e.g., Montreuil \& Bourhis, 2001 for valued vs. devalued immigrant groups; see also Ford, 2011; Schalk-Soekar, van de Vijver, \& Hoogsteder, 2004). Thus, the low status assigned to Senegalese migrants may explain why experiences of discrimination constituted a systematic pathway to transnational political involvement. Though perceived discrimination was not extensively reported, it is presumably higher among African than among European migrants.

Unexpectedly, cultural maintenance was unrelated to transnational activities. To understand this finding one should consider that political action may not allow promoting cultural maintenance as an acculturation strategy. First, maintaining one's culture does not necessarily require public political activities in the country of origin but can be pursued in private, everyday settings (e.g., eating habits, language, religious practice; see Arends-Tóth \& van de Vijver, 2004). Second, cultural maintenance, as assessed in the current study, taps into ethnic visions of nationhood, endorsing for example common ancestral values and religious traditions, whereas transnational political involvement represents civic aspects of nationhood based on common citizenship and participation in public life (see Smith, 2001). Both factors may explain the absence of link between cultural maintenance and transnational political activities. Consequently, instead of political involvement, desire for cultural maintenance may underlie participation in transnational activities that promote the culture of the country of origin.

One must keep in mind that the collective action model we drew on was developed to understand political action, such as protesting against political or societal events. Transnational political activities encompass a wider range of political behaviour and motivations. Participating in activities aiming to develop one's home country, region or village may be driven by different mechanisms. In the current research, we assessed generic participation in and support for political parties and NGOs but future research should distinguish between activities aimed, for example, at the development of infrastructures, improving the social system, and supporting or changing the political regime. Moreover, migrants' political participation is influenced by the openness of the political opportunity structures (e.g., citizenship and integration regimes) in receiving countries and the situation in countries of origin (Fennema \& Tillie, 1999; Koopmans, Statham, Giugni, \& Passy, 2005; for a similar argument for acculturation strategies see Navas et al., 2005), which need to be considered too in future research.

Overall, our results suggest that the public and political concern that transnational activities and lack of cultural adoption as well as disloyalty to the receiving country go hand in hand is unwarranted. Previously in transnationalism research, cultural adaptation has been assessed with structural indicators, such as length of stay and language skills. The findings of our research contribute to this literature by showing that the subjective desire to belong to receiving country underlies transnational behaviour. Moreover, to our knowledge, up to now in acculturation research, psychological and intergroup outcomes of acculturation preferences have mainly been studied (see van Oudenhoven et al., 2006), whereas we showed links with transnational political involvement. The current research should be extended by investigating links between acculturation behaviour (i.e., not preferences, but actual acculturation strategies such as organisation of social and family relationships, consumer habits, or customs) and transnational activities (e.g., Navas et al., 2005; Ward \& Kus, 2012). Accounting for the different migration patterns among migrants, when examining the relationship between acculturation preferences and transnational behaviour, is another fruitful avenue for future research (Engbersen, Leerkes, Grabowska-Lusinska, Snel, \& Burgers, 2013 for an example on labour migrants in the Netherlands).

\subsection{Limits}

To conclude, caveats of our study need to be discussed too. First, due to the cross-sectional nature of our data, the revealed relationships are difficult to unpick. We obviously cannot draw unequivocal causal conclusions about the impact 
of acculturation preferences and perceived discrimination on transnational political involvement. For example, knowledge gained in the activities of transnational associations can be employed in dealing with issues in the receiving country (Vertovec, 2009). Such empowerment can then bolster desire for cultural adoption or integration. A reciprocal or synergistic relationship is also plausible for example such that transnational political involvement affects acculturation preferences and vice versa (Erdal \& Oeppen, 2013). Our model, however, drew on theorising and evidence from collective action research increasing our confidence in the findings. Importantly, the data at hand allows concluding that participation in transnational political activities and desire to adopt the culture of the receiving country are compatible.

Second, we must acknowledge that the size of the sample was small. While the moderate effect sizes of the revealed main effects make us confident of the findings, the low sample size may have been more of an issue for the calculation of interaction effects (Aguinis, 1995; see also Cohen, 1992). For this reason, we performed robust regression analyses. Moreover, to assure the stability of our findings, additional analyses were conducted excluding sociodemographic predictors. The findings were unaltered. Despite these precautions, it is nevertheless possible that some interaction effects were undetected.

Third, because an important part of the entire research project focussed on transnational activities of associations, the study was conducted only among members of different Senegalese migrant associations and Dahiras (religious associations) that were assumed to be involved in transnational activities. This partially explains the small sample size. Though migrant associations are of similar importance for the diaspora in both Geneva and Paris, the focus of different associations varies (Maggi et al., 2013). The questionnaires were administered in associations mainly involved in political, spiritual, and broader development activities. Members of such associations are frequently students or former students, which is less the case for associations focussing on development of home villages. The sample thus included a large proportion of highly educated Senegalese, which does not represent the overall composition of Senegalese migrants, in particular in Paris. Consequently, generalisations to the entire Senegalese communities in both cities are unwarranted. Education enables access to jobs with higher qualifications and networks including host country members. Indeed, transnational activities are consistently associated with more education and higher occupational status (Portes, 2003). Kaag (2013) for example describes the diversification of the Senegalese Murid communities in Italy in terms of educational and social background and highlights transnational activities among a new elite of educated men. Yet, while the specificity of the sample may influence mean levels of political involvement and the strength of relationships with acculturation preferences and perceived discrimination, there is no reason to expect that the direction of relationships was affected. It is worth noting that though participants were members of associations, personally they were moderately involved in transnational politics. This is consistent with previous research showing that migrants' transnational political engagement is occasional for instance in response to elections or economic downturns (Levitt \& Jaworsky, 2007; see also van Bochove, 2012).

\section{Conclusion}

Transnational behaviour is omnipresent-despite interindividual and intercommunity variation-among new as well as old migrants in the ever more globalised world (Vertovec, 2009; see also Berry, 2008, on links between acculturation and globalisation). It is thus crucial to understand how the dynamic nature of acculturation preferences, involving negotiations between the values and norms of the countries of origin and of residence, shape family, cultural, economic, and political cross-border links between migrants. Transnationalism scholars have called for more attention on migrants' agency to further uncover the co-existence and interactions between processes of integration and transnationalism (Erdal \& Oeppen, 2013). In this regard, the current research contributes to understanding how the relationships migrants desire with and the way they feel treated by the receiving country shape transnational political involvement. Our focus on both transnational motivations and self-reported political behaviour, examining mechanisms revealed in collective action research, puts political psychology at the nexus between acculturation psychology and transnationalism studies.

\section{Acknowledgements}

This work was supported by the Swiss Network for International Studies (SNIS) (Grant No. P-2009-234). We thank Nicole Fasel and Robert Baur for helpful comments on a previous draft.

\section{References}

Aguinis, H. (1995). Statistical power with moderated multiple regression in management research. Journal of Management, 21, 1141-1158. http://dx.doi.org/10.1177/014920639502100607

Aiken, L. S., \& West, S. G. (1991). Multiple regression: Testing and interpreting interactions. Newbury Park, CA: Sage

Al-Ali, N., Black, R., \& Koser, K. (2001). The limits to 'transnationalism': Bosnian and Eritrean refugees in Europe as emerging transnational communities. Ethnic and Racial Studies, 24, 578-600. http://dx.doi.org/10.1080/01419870120049798

Alba, R., \& Nee, V. (1997). Rethinking assimilation theory for a new era of immigration. International Migration Review, $31,826-874$.

Antonakis, J., Bendahan, S., Jacquart, P., \& Lalive, R. (2010). On making causal claims: A review and recommendations. Leadership Quarterly, 21, 1086-1120. http://dx.doi.org/10.1016/j.leaqua.2010.10.010

Arends-Tóth, J., \& van de Vijver, F. J. R. (2004). Domains and dimensions in acculturation: Implicit theories of Turkish-Dutch. International Journal of Intercultural Relations, 28, 19-35. http://dx.doi.org/10.1016/j.ijintrel.2003.09.001

Basch, L., Glick Schiller, N., \& Blanc-Szanton, C. (1994). Nations unbound. Transnational projects, postcolonial predicaments, and deterritorialized nation-states. Amsterdam: Gordon and Breach. 
Beque, M. (2005). Le vécu des attitudes intolérantes ou discriminatoires par les personnes immigrées et issues de l'immigration [The experiences of intolerant and discriminatory attitudes among immigrants and people with immigrant origin]. DREES Direction de la Recherche des Etudes de l'Evaluation et des Statistiques, 424. Ministère de l'emploi, du travail et de la cohésion sociale/Ministère de la santé et de la protection sociale, France [French Ministry of Employment, Work and Social Cohesion/Ministry of health and social protection].

Bermudez, A. (2010). The transnational political practices of Colombians in Spain and the United Kingdom: Politics 'here' and 'there'. Ethnic and Racial Studies, 33, 75-91. http://dx.doi.org/10.1080/01419870903125838

Berry, J. W. (1990). Psychology of acculturation. In J. Berman (Ed.), Cross-cultural perspectives (Nebraska Symposium on Motivation) (Vol. 37) (pp. 201-234). Lincoln, NE: University of Nebraska Press.

Berry, J. W. (2006a). Contexts of acculturation. In D. L. Sam, \& J. W. Berry (Eds.), The Cambridge handbook of acculturation psychology (pp. 27-42). Cambridge, UK: Cambridge University Press.

Berry, J. W. (2006b). Stress perspectives on acculturation. In D. L. Sam, \& J. W. Berry (Eds.), The Cambridge handbook of acculturation psychology (pp. 43-57). Cambridge: Cambridge University Press.

Berry, J. W. (2008). Globalisation and acculturation. International Journal of Intercultural Relations, 32, 328-336. http://dx.doi.org/10.1016/ j.ijintrel.2008.04.001

Berry, J. W., \& Sabatier, C. (2010). Acculturation, discrimination, and adaptation among second generation immigrant youth in Montreal and Paris. International Journal of Intercultural Relations, 34, 191-207. http://dx.doi.org/10.1016/j.ijintrel.2009.11.007

Berry, J. W., \& Sabatier, C. (2011). Variations in the assessment of acculturation attitudes: Their relationships with psychological wellbeing. International Journal of Intercultural Relations, 35, 658-669. http://dx.doi.org/10.1016/j.ijintrel.2011.02.002

Bloch, D. A. (2008). Zimbabweans in Britain: Transnational activities and capabilities. Journal of Ethnic and Migration Studies, 34, 287-305. http://dx.doi.org/10.1080/13691830701823822

Bourhis, R. Y., Moïse, L. C., Perreault, S., \& Senécal, S. (1997). Towards and interactive acculturation model: A social psychological approach. International Journal of Psychology, 32, 369-383. http://dx.doi.org/10.1080/002075997400629

Brown, R., \& Zagefka, H. (2011). The dynamics of acculturation: An intergroup perspective. In J. M. Olson, \& M. P. Zanna (Eds.), Advances in experimental social psychology (pp. 129-184). Burlington: Academic Press.

Carling, J., \& Hoelscher, K. (2013). The capacity and desire to remit: Comparing local and transnational influences. Journal of Ethnic and Migration Studies, 39, 939-958. http://dx.doi.org/10.1080/1369183X.2013.765657

Cohen, J. (1992). Power primer. Psychological Bulletin, 112(1), 155-159. http://dx.doi.org/10.1037/0033-2909.112.1.155

Davidov, E., \& De Beuckelaer, A. (2010). How harmful are survey translations? A test with Schwartz's human values instrument. International Journal of Public Opinion Research, 22, 485-510. http://dx.doi.org/10.1093/ijpor/edq030

Deaux, K., Reid, A., Martin, D., \& Bikmen, N. (2006). Ideologies of diversity and inequality: Predicting collective action in groups varying in ethnicity and immigrant status. Political Psychology, 27, 123-146. http://dx.doi.org/10.1111/j. 1467-9221.2006.00452.x

Engbersen, G., Leerkes, A., Grabowska-Lusinska, I., Snel, E., \& Burgers, J. (2013). On the differential attachments of migrants from central and Eastern Europe: A typology of labour migration. Journal of Ethnic and Migration Studies, 39, 959-981. http://dx.doi.org/10.1080/1369183X.2013.765663

Erdal, M. B., \& Oeppen, C. (2013). Migrant balancing acts: Understanding the interactions between integration and transnationalism. Journal of Ethnic and Migration Studies, 39, 867-884. http://dx.doi.org/10.1080/1369183X.2013.765647

Faist, T. (2008). Migrants as transnational development agents: An inquiry into the newest round of the migration-development nexus. Population, Space and Place, 14, 21-42. http://dx.doi.org/10.1002/psp.471

Fall, P. D., Hernández Carretero, M., \& Sarr, M. Y. (2010). Senegal Country and research areas report (project paper). Retrieved from Eumagine: http://www.eumagine.org/outputs/PP2\%20-\%20Senegal\%20Country\%20and\%20Research\%20Areas\%20Report\%20-\%20Final.pdf

Fennema, M., \& Tillie, J. (1999). Political participation and political trust in Amsterdam: Civic communities and ethnic networks. Journal of Ethnic and Migration Studies, 25, 703-726. http://dx.doi.org/10.1080/1369183X.1999.9976711

Ford, R. (2011). Acceptable and unacceptable immigrants: How opposition to immigration in Britain is affected by migrants' region of origin. Journal of Ethnic and Migration Studies, 37, 1017-1037. http://dx.doi.org/10.1080/1369183X.2011.572423

Global Forum on Migration and Development (GFMD). (2007). Summary report of the first meeting. Brussels.

Guarnizo, L. E., Portes, A., \& Haller, W. (2003). Assimilation and transnationalism: Determinants of transnational political action among contemporary migrants. American Journal of Sociology, 108, 1211-1248. http://dx.doi.org/10.1086/375195

Heath, A., Martin, J., \& Spreckelsen, T. (2009). Cross-national comparability of survey attitude measures. International Journal of Public Opinion Research, 21, 293-315. http://dx.doi.org/10.1093/ijpor/edp034

Jasinskaja-Lahti, I., Liebkind, K., Horenczyk, G., \& Schmitz, P. (2003). The interactive nature of acculturation: Perceived discrimination, acculturation attitudes and stress among young ethnic repatriates in Finland, Israel and Germany. International Journal of Intercultural Relations, $27,79-97$. http://dx.doi.org/10.1016/S0147-1767(02)00061-5

Jasinskaja-Lahti, I., Liebkind, K., \& Solheim, E. (2009). To identify or not to identify? National disidentification as an alternative reaction to perceived ethnic discrimination. Applied Psychology, 58, 105-128. http://dx.doi.org/10.1111/j.1464-0597.2008.00384.x

Kaag, M. (2013). Transnational elite formation: The Senegalese Murid community in Italy. Journal of Ethnic and Migration Studies, 39, $1425-1439$. http://dx.doi.org/10.1080/1369183X.2013.815410

Kivisto, P. (2001). Theorizing transnational immigration: A critical review of current efforts. Ethnic and Racial Studies, 24 , 549-577. http://dx.doi.org/10.1080/01419870120049789

Klandermans, B., van der Toorn, J., \& van Stekelenburg, J. (2008). Embeddedness and identity: How immigrants turn grievances into action. American Sociological Review, 73, 992-1012. http://dx.doi.org/10.1177/000312240807300606

Koopmans, R., Statham, P., Giugni, M., \& Passy, F. (2005). Contested citizenship. Immigration and cultural diversity in Europe. Minneapolis, MN: University of Minnesota Press.

Lacroix, D. T. (2009). Transnationalism and development: The example of Moroccan migrant networks. Journal of Ethnic and Migration Studies, 35, 1665-1678. http://dx.doi.org/10.1080/13691830903165865

Lacroix, T., Sall, L., \& Salzbrunn, M. (2008). Marocains et Sénégalais de France: Permanences et évolution des relations transnationales [Moroccans and Senegalese of France: Permanence and evolution of transnational relations]. Revue Européenne des Migrations Internationales, $24,23-43$.

Levitt, P., \& Jaworsky, B. N. (2007). Transnational migration studies: Past developments and future trends. Annual Review of Sociology, 33, 129-156. http://dx.doi.org/10.1146/annurev.soc.33.040406.131816

Maggi, J., Sarr, D., Green, E. G. T., Sarrasin, O., \& Ferro, A. (2013). (Transnational Senegalese migrations, integration and development. The role of diaspora organizations in Milan, Paris and Geneva) Migrations transnationales sénégalaises, intégration et développement. Le rôle des associations de la diaspora à Milan, Paris et Genève. In Sociograph - Sociological Research Studies N ${ }^{\circ}$ 15. Department of sociology, University of Geneva.

Montreuil, A., \& Bourhis, R. Y. (2001). Majority acculturation orientations toward valued and devalued immigrants. Journal of Cross-Cultural Psychology, 32, 698-719. http://dx.doi.org/10.1177/0022022101032006004

Navas, M., Garcia, M. C., Sanchez, J., Rojas, A. J., Pumares, P., \& Fernandez, J. S. (2005). Relative Acculturation Extended Model (RAEM): New contributions with regard to the study of acculturation. International Journal of Intercultural Relations, 29, 21-37. http://dx.doi.org/10.1016/j.ijintrel.2005.04.001

Phalet, K., \& Kosic, A. (2006). Acculturation in an enlarged European context. In D. K. Sam, \& J. W. Berry (Eds.), Cambridge handbook of acculturation psychology (pp. 331-348). Cambridge: Cambridge University Press.

Portes, A. (2001). Introduction: The debates and significance of immigrant transnationalism. Global Networks, 1, 181-194. http://dx.doi.org/ $10.1111 / 1471-0374.00012$

Portes, A. (2003). Conclusion: Theoretical convergences and empirical evidence in the study of immigrant transnationalism. International Migration Review, 37, 874-892. http://dx.doi.org/10.1111/j.1747-7379.2003.tb00161.x 
Riccio, B. (2005). Talkin' about migration - Some ethnographic notes on the ambivalent representation of migrants in contemporary Senegal. Wiener Zeitschrift für kritische Afrikastudien, 8, 99-118.

Sam, D. L., \& Berry, J. W. (2006). Cambridge handbook of acculturation psychology. Cambridge: Cambridge University Press.

Schalk-Soekar, S. R. G., van de Vijver, F. J. R., \& Hoogsteder, M. (2004). Attitudes toward multiculturalism of immigrants and majority members in the Netherlands. International Journal of Intercultural Relations, 28, 533-550. http://dx.doi.org/10.1016/j.ijintrel.2005.01.009

Schmitt, M. T., \& Branscombe, N. R. (2002). The meaning and consequences of perceived discrimination in disadvantaged and privileged social groups. In W. Stroebe, \& M. Hewstone (Eds.), European review of social psychology (pp. 167-199). Chichester, England: Wiley.

Simon, B., \& Grabow, O. (2010). The politicization of migrants: Further evidence that politicized collective identity is a dual identity. Political Psychology, 31, 717-738. http://dx.doi.org/10.1111/j.1467-9221.2010.00782.x

Smith, A. D. (2001). Nationalism: Theory, ideology, history. Cambridge: Polity Press.

Smith, M. P., \& Bakker, M. (2008). Citizenship across borders: The political transnationalism of El Migrante. Ithaca, NY: Cornell University Press.

Snel, E., Engbersen, G., \& Leerkes, A. (2006). Transnational involvement and social integration. Global Networks, 6, 285-308. http://dx.doi.org/10.1111/ j.1471-0374.2006.00145.x

Some, A. N. (2009). (Migration in Senegal. National profile 2009) Migration au Sénégal. Profil National 2009. Geneva: International Organization for Migration.

Stürmer, S., \& Simon, B. (2004). Collective action: Towards a dual-pathway model. European Review of Social Psychology, 15, 59-99. http://dx.doi.org/ $10.1080 / 10463280340000117$

Tamaki, E. (2011). Transnational home engagement among Latino and Asian Americans: Resources and motivation. International Migration Review, 45, 148-173. http://dx.doi.org/10.1111/j.1747-7379.2010.00842.x

Taylor, D. M., Wright, S. C., Moghaddam, F. M., \& Lalonde, R. N. (1990). The personal/group discrimination discrepancy: Perceiving my group, but not myself, to be a target for discrimination. Personality and Social Psychology Bulletin, 16, 254-262. http://dx.doi.org/10.1177/0146167290162006

Te Lindert, A., Korzilius, H., Van de Vijver, F. J. R., Kroon, S., \& Arends-Tóth, J. (2008). Perceived discrimination and acculturation among Iranian refugees in the Netherlands. International Journal of Intercultural Relations, 32, 578-588. http://dx.doi.org/10.1016/j.ijintrel.2008.09.003

Van Bochove, M. (2012). Truly transnational: The political practices of middle-class migrants. Journal of Ethnic and Migration Studies, 38, 1551-1568. http://dx.doi.org/10.1080/1369183X.2012.711042

Van Oudenhoven, J. P., \& Ward, C. (2013). Fading majority cultures: The implications of transnationalism and demographic changes for immigrant acculturation. Journal of Community E Applied Social Psychology, 23, 81-97. http://dx.doi.org/10.1002/casp.2132

Van Oudenhoven, J. P., Ward, C., \& Masgoret, A. M. (2006). Patterns of relations between immigrants and host societies. International Journal of Intercultural Relations, 30, 637-651. http://dx.doi.org/10.1016/j.ijintrel.2006.09.001

Van Stekelenburg, J. (2013). The political psychology of protest: Sacrificing for a cause. European Psychologist, 18, 224-234. http:/dx.doi.org/ $10.1027 / 1016-9040 / a 000156$

van Zomeren, M., Postmes, T., \& Spears, R. (2008). Toward an integrative social identity model of collective action: A quantitative research synthesis of three socio-psychological perspectives. Psychological Bulletin, 134, 504-535. http://dx.doi.org/10.1037/0033-2909.134.4.504

Verkuyten, M., \& Martinovic, B. (2012). Immigrants' national identification: Meanings, determinants, and consequences. Social Issues and Policy Review, 6, 82-112. http://dx.doi.org/10.1111/j.1751-2409.2011.01036.x

Verkuyten, M., \& Thijs, J. (2002). Multiculturalism among minority and majority adolescents in the Netherlands. International Journal of Intercultural Relations, 26, 91-108. http://dx.doi.org/10.1016/S0147-1767(01)00039-6

Verkuyten, M., \& Yildiz, A. A. (2006). The endorsement of minority rights: The role of group position, national context, and ideological beliefs. Political Psychology, 27, 527-548. http://dx.doi.org/10.1111/j.1467-9221.2006.00525.x

Vertovec, S. (2007). Super-diversity and its implications. Ethnic and Racial Studies, 30, 1024-1054. http://dx.doi.org/10.1080/01419870701599465

Vertovec, S. (2009). Transnationalism. London \& New York: Routledge.

Ward, C., \& Kennedy, A. (1999). The measurement of sociocultural adaptation. International Journal of Intercultural Relations, 23 , 659-677. http://dx.doi.org/10.1016/S0147-1767(99)00014-0

Ward, C., \& Kus, L. (2012). Back to and beyond Berry's basics: The conceptualization, operationalization and classification of acculturation. International Journal of Intercultural Relations, 36, 472-485. http://dx.doi.org/10.1016/j.ijintrel.2012.02.002

White, H. (1980). A heteroskedasticity-consistent covariance matrix estimator and a direct test for heteroskedasticity. Econometrica, $48,817-838$. 